\begin{tabular}{||r|c|c||}
\hline Received: September 2018 & Accepted: October 2018 & Published: October 2018 \\
\hline \hline Article DOI: http://dx.doi.org/10.24903/sj.v3i2.246 \\
\hline
\end{tabular}

\title{
The Effectiveness of Flip Classroom with Student Teams-Achievement Divisions (STAD) Method to Teach Reading Viewed from Students' English Learning Interest
}

\author{
Sunarti \\ Universitas Muhammadiyah Kalimantan Timur \\ sun377@umkt.ac.id \\ Dzul Rachman \\ Universitas Muhammadiyah Kalimantan Timur \\ dzulrachman@umkt.ac.id
}

\begin{abstract}
The study is aimed: (1) To know whether Flip Classroom with STAD method is more effective than Traditional Instruction to teach reading; (2) to know whether the students who have high learning interest have better reading comprehension than those who have low learning interest; and (3) to know whether there is an interaction between Flip Classroom with teaching methods and students' learning interest. The population of the research is the First year students of Public Health. The samples were from two classes. In taking the sample, cluster random sampling approach was used. Each class was divided into two groups (the students who have high and low learning interest). Then, the techniques which have been used to accumulate the information had been questionnaire student learning interest and reading test. The data were analyzed by using multifactor analysis of ANOVA $2 \times 2$ and Tuckey test. There are some research findings: (1) Flip Classroom with STAD method is more effective than Traditional Instruction to teach reading; (2) the reading comprehension of the students who have high learning interest is better than that of those who have low learning interest because; and (3) there is an interaction between teaching methods and learning interest for teaching reading. It is concluded that there is an interaction impact among methods and students' learning interest for teaching reading. Flip Classroom with STAD is suitable for students having high learning interest and Traditional Instruction is suitable for students having low learning interest.
\end{abstract}

Keywords: Flip classroom, Student Teams-Achievement Divisions (STAD), Teaching Reading, English Learning Interest. 


\section{INTRODUCTION}

In comprehending the message of a text, reading can function as a communicative process between a writer and a reader. According to (Westwood, 2001), a reader's understanding of text is influenced by a broad range of factors, including his or her motivation, interest, vocabulary, general knowledge, knowledge of particular subject, word identification skills, reasoning ability, use of effective strategies to identify main ideas and supporting detail, and an appreciation of text structure.

In general, the goals of reading are categorized into various types, along with getting fashionable facts from a textual content, getting precise facts from a textual content and analyzing for interest. Furthermore, studying enables the reader to address any sort of texts and also facilitates her or him examine with none assistance. It enables her or him to gain the reading ability in such bendy velocity wanted as the signal of a competent reader. It additionally helps in gaining a competence in silent reading ability because this talent can enhance comprehension. Analyzing can also assist the students to learn to think in the new language and additionally enhance their vocabulary. Eventually, the students can expand their information approximately the whole thing.

Educators attempt to come up with new teaching and mastering tactics to manage up with the evolving requirements and options of beginners. The development of records generation has affected the way we teach and learn and as a result, offers possibilities to enrich the learning surroundings. The Flipped learning is a quite new version of training that has the potential to regulate the conventional manner of turning in the learning material to gain extra effective getting to know results. First, it's miles relevant to provide a comprehensive definition of the time period Flipped learning which will give the reader the large picture at the back of this technique. The term Flipped learning is defined as a "pedagogical method in which direct instruction moves from the group gaining knowledge of area to the character mastering area, and the resulting group area is converted right into a dynamic, interactive learning environment where the educator guides college students as they practice standards and interact creatively in the issue be counted" (Network, 2014).

Large class is a reality found in some educational institutions, both schools and colleges. A monotonous studying manner in a class over than forty college students will create stupid classrooms and do no longer even involve college students in any teaching and mastering method. So the mastering procedure has a tendency to cognizance on instructors as opposed to on college students. Teachers appear tough to deal with huge numbers of college 
students, academics are tired of absolute awareness, and a shortage of interplay among school and college students. In a huge classroom, a couple or organization of college students can help each different and research from every other. It is far genuinely supported with the aid of the choice of appropriate strategies or coaching strategies.

The above trouble is the heritage of the researcher to have a look at related troubles in the getting to know technique which has the number of students above forty. Group learning is believed in a position to conquer the problem of huge classes. is the most effective of all cooperative gaining knowledge of methods. Because of this, the author chooses it as a starting point of applying cooperative getting to know in the studies. STAD consists of five major components - class presentations, teams, quizzer, individual improvement scores, and team recognitions.

So, in using Flip classroom expected students are able to comprehend text optimally before the class meeting. And through STAD method in learning process in the classroom, students work on worksheet in their teams to master the material learned in advance and to help the teammates master the material. In learning process each member is responsible to group success. According to (Stone, 2012) states that one of advantage of flip learning in higher education is increased engagement in the learning material: in the traditional learning environment, class time is devoted to the delivery of learning material, which limits the time for active interaction of students with the learning content. In the flipped learning environment, students are encouraged to be active participants in the leaning process by interacting with the learning material, asking questions, and receiving personalized and instant feedback.

The statements of the problem are formulated as follows: (1) Is Flip Classroom more effective than traditional Instruction to teach reading at the First year Students of public health department; (2) Do the students who have high learning interest have better reading achievement than those who have low learning interest at the First year Students of public health department; and (3) Is there any interaction between teaching strategies and students' learning interest to teach reading at the First year Students of public health department.

\section{METHODOLOGY}

This research took place at the first year students of Universitas Muhammadiyah Kalimantan Timur, East Kalimantan Province. The design of this research was simple Factorial Design. Factorial designs amplify the wide variety of relationships that may be 
examined in an experimental have a look at. They may be basically modifications of either the posttest-handiest manage group or pretest-posttest manipulate group designs, which allow the investigation of additional impartial variables (Fraenkel and Wallen, 2000).

In this research, there were two groups, experimental group and control group, the experimental group was taught by using Flip Classroom in STAD method while control group was taught by using Traditional Instruction. Both groups were given a questionnaire to classify them into students with high English learning interest and the ones with low English learning interest. By combining the multiple observers, theories, and material, the researcher tried to overcome the weakness or biases and the problems the process (Nur, 2017). In focuses are the mainly to raw score and mean (Arbain, 2017).

(Fraenkel and Wallen, 2000) in nation that population is the bigger group to which one hopes to use the outcomes. There are two instructions which every elegance consists of 50 students. The pattern on this study had been each training of Public health department. Once you have the sample, the writer divided the pattern into two organization, Experimental group and manipulate organization, after which every magnificence changed into divided into groups, college students who've high mastering hobby and those who've low mastering interest. To categorise the students in every class into those who have high and coffee learning interest, the researcher used the median of learning interest scores. In this study, the sample changed into taken through the use of cluster random sampling from the population.

This research used a simple Factorial design $2 \times 2$. This research used two independent variable: Flip Classroom and Traditional instruction, and attributive variable: students' interest in learning English. The research design is as follows:

\begin{tabular}{|c|c|c|}
\hline Metods & $\begin{array}{c}\text { Flip } \\
\text { Classroom } \\
\text { with } \\
\text { STAD }\end{array}$ & Traditional \\
Interest & $\left(A_{1}\right)$ & $\left(A_{2}\right)$ \\
\hline High $\left(B_{1}\right)$ & $\mathrm{A}_{1} \mathrm{~B}_{1}$ & $\mathrm{~A}_{2} \mathrm{~B}_{1}$ \\
\hline Low $\left(B_{2}\right)$ & $\mathrm{A}_{1} \mathrm{~B}_{2}$ & $\mathrm{~A}_{2} \mathrm{~B}_{2}$ \\
\hline
\end{tabular}


The Effectiveness of Flip Classroom with Student Teams-Achievement Divisions (STAD) Method to Teach Reading Viewed from Students' English Learning Interest

Sunarti, Dzul Rachman

\begin{tabular}{|l|l|l|}
\hline Mean Score & $A_{1}$ & $A_{2}$ \\
\hline
\end{tabular}




\section{FINDINGS AND DISCUSSION}

Testing hypothesis can be done after the data are normal and homogeneous through normality and homogeneity test. Furthermore, the data analysis must be conducted systematically in order that the result of the analysis is scientifically accepted. the researcher analyzes the data using multifactor analysis of variance.

\begin{tabular}{lllll}
\hline \multicolumn{1}{c}{ Source of } & SS & DF & MS & F $_{\mathbf{0}}$ \\
variance & & & & \\
\hline Between & 70.416 & 1 & 70.416 & $\mathbf{1 2 . 0 6}$ \\
columns & & & & \\
Between & 62.016 & 1 & 62.016 & $\mathbf{1 0 . 6 2}$ \\
Rows & & & & \\
Columns & 442.816 & 1 & 442.816 & $\mathbf{7 5 . 8 5}$ \\
by rows & & & & \\
Between & 575.25 & 3 & 191.75 & \\
groups & & & & \\
Within & & & & \\
groups & 326.933 & 96 & $\mathbf{5 . 8 3 8}$ & \\
Total & & & & \\
\hline & & & & \\
\hline
\end{tabular}

Table 1 The summary of a 2 X 2 multifactor analysis of variance

Based on the summary of a 2 x 2 Multifactor Analysis of Variance, it can be concluded that Firstly, $F_{0}$ between columns (12.06) is higher that $F_{t}(4.03)$ at the level of significance $(\alpha)=0.05$ and $F_{t}(7.17)$ at the level of significance $(\alpha)=0.01$, so the difference between columns is significant. It can be concluded that teaching Reading using Flip Classroom with STAD method to the students of Public Health department is significantly 
different from the one using Traditional Instruction. The mean score of students who are taught using Flip Classroom with STAD (28.20) is higher than the mean score of students who are taught using Traditional Instruction (26.03). It means that teaching Reading using Flip Classroom with STAD method is more effective than the one using Traditional Instruction for the students.

Secondly, $F_{0}$ between rows (10.62) is higher than $F_{t}(4.03)$ at the level of significance $(\alpha)=0.05$ and $F_{t}(7.17)$ at the level of significance $(\alpha)=0.01$, so the difference between rows is significant. It can be concluded that the achievement of students who have high and those who have low learning interest are significantly different. The mean score of the students having high learning interest (28.13) is higher than the one of those having low learning interest (26.10). It means that the reading achievement of the students having high learning interest is better than the one of those having low learning interest. Thirdly, $\mathrm{F}_{0}$ interaction (75.85) is higher than $F_{t}(4.03)$ at the level of significance $(\alpha)=0.05$ and $F_{t}(7.17)$ at the level of significance $(\alpha)=0.01$, so there is interaction between the two variables, the teaching methods and learning interest to teach reading.

After using multifactor analysis of variance, the researcher analyzes the data using Tuckey test. The following is analysis of the data using Tuckey test.

\begin{tabular}{ccccc} 
Cells & \multicolumn{1}{c}{$\mathbf{q}_{\mathbf{0}}$} & \multicolumn{2}{c}{$\mathbf{q}_{\mathbf{t}}$} & Status \\
& & $\mathbf{0 . 0 5}$ & $\mathbf{0 . 0 1}$ & \\
& & & & \\
$\mathbf{A}_{\mathbf{1}^{-}}$ & 4.91 & 2.89 & 3.89 & Significant \\
$\mathbf{A}_{\mathbf{2}}$ & & & & \\
$\mathbf{B}_{\mathbf{1}^{-}}$ & 4.61 & 2.89 & 3.89 & Significant \\
$\mathbf{B}_{\mathbf{2}}$ & & & & \\
$\mathbf{A}_{\mathbf{1}} \mathbf{B}_{\mathbf{1}^{-}}$ & 12.18 & 3.01 & 4.17 & Significant \\
$\mathbf{A}_{2} \mathbf{B}_{\mathbf{1}}$ & & & & \\
$\mathbf{A}_{\mathbf{1}} \mathbf{B}_{\mathbf{2}^{-}}$ & 5.24 & 3.01 & 4.17 & Significant \\
$\mathbf{A}_{\mathbf{2}} \mathbf{B}_{\mathbf{2}}$ & & & & \\
\hline
\end{tabular}




\section{Table 2 The summary of Tuckey test}

From the summary of Tuckey test, it can be concluded that based on this result $\left(q_{o}>q_{t}\right)$ $(4.91>2.89)$ and the result of ANOVA $\left(F_{o}>F_{t}\right)(12.06>4.03)$ at the level of significance $(\alpha)$ $=0.05, \mathrm{H}_{\mathrm{o}}$ is rejected and $\mathrm{H}_{1}$ which states that Flip classroom with STAD method is more effective than Traditional Instruction to teach reading is accepted. Secondly, based on this result $\left(\mathrm{q}_{\mathrm{o}}>\mathrm{q}_{\mathrm{t}}\right)(4.61>2.89)$ and the result of ANOVA $\left(\mathrm{F}_{\mathrm{o}}>\mathrm{F}_{\mathrm{t}}\right)(10.62>4.03)$ at the level of significance $(\alpha)=0.05, \mathrm{H}_{\mathrm{o}}$ is rejected and $\mathrm{H}_{1}$ which states that students having high learning interest have better reading achievement than students having low learning interest is accepted.

Thirdly, because $\mathrm{q}_{0}$ between columns (HI) (12.18) is higher than $\mathrm{q}_{\mathrm{t}}(3.01)$ at the level of significance $(\alpha)=0.05$, the difference between columns is significant. It can be concluded that teaching reading using flip classroom to the students having high learning interest is more effective than using Traditional Instruction. Fourthly, Because $\mathrm{q}_{0}$ between columns (LI) (5.24) is higher than $\mathrm{q}_{\mathrm{t}}(3.01)$ at the level of significance $(\alpha)=0.05$, It can be concluded that teaching vocabulary using Traditional Instruction to the students having low learning interest is more effective than those having low learning interest taught using Flip Classroom. Based on the result of point 3 and 4, Flip Classroom is more effective to teach reading than Traditional Instruction for students having high learning interest and Traditional Instruction is more effective to teach reading than Flip Classroom for students having low learning interest, it can be concluded that there is an interaction between the teaching strategies and the students' learning interest in teaching reading, and based on the result of ANOVA $\left(F_{o}>F_{t}\right)$ (75.85 > 4.03), $\mathrm{H}_{\mathrm{o}}$ is rejected and $\mathrm{H}_{1}$ which states that there is interaction between teaching methods and learning interest in teaching reading is accepted.

The followings are the discussions of the research finding: There the significant difference between teaching reading using Flip Classroom with STAD method and using Traditional Instruction. Flip Classroom with STAD method is group learning model which emphasizes on group members' collaboration in mastering the learning materials. After understanding material individually and informally by Flip Classroom, then in the classroom, the group has the responsibility in tutoring their members, and/or sharing knowledge with each other. Teaching reading using Flip Classroom with STAD method is able to arouse the students' involvement in teaching learning process, students are encouraged to involve during the group learning activity. 
In group learning, the students' motivation is called to contribute to their successful team. Furthermore, the students can easily master and memorize the lack of new words and their form through their interaction in the team, each student shows their enthusiastic in the learning process and they are much interested in learning reading. As a result, their vocabulary achievement can surely be improved optimally. (McConel, 2006) states use small-group discussion is an effective way of encouraging all students to participate. When the teacher teaches by using Flip Classroom with STAD method, the class atmosphere changes into a better one and the students are much more interested in the teaching and learning process. The effort of efficiency time is running well. And each student contributes to positive competition among the teams during the learning process. They individually in team try hard to do their best to be a great team by carefully paying attention to their team work. In the class learning activity, students gain more from a class discussion when they actively participate in it, and they are more likely to speak openly when their audience is a handful of classmates rather than the class as a whole.

Secondly, the reading achievement of the students with high learning interest is better than the one of those with low learning interest. The students who have high learning interest have better reading achievement than those who have low learning interest. Students who have high learning interest are indicated always active, creative, curious, had good participation in the teaching and learning process. They have their own spirit and motivation to study for getting their best competency and skill, otherwise, because of their curiosity, they like to have a challenging activity in learning vocabulary. According to (Hurlock, 1983), the interest will add enjoyment to any activity that the individual engages in. If students are interested in an activity, the experiences will be far more enjoyable than if they are bored. Students' interest in learning English is very important.

Their learning interest influences their achievement in learning English. The students having low learning interest are indicated, such as: individualistic, unconfident, irresponsible, lack of leadership, and subjective thinking. The teacher identifies that the students with low learning interest are reluctant to actively participate in the teaching and learning process during the class session. They lazily involve in the class discussion. They do not have enough intention in learning reading. Thirdly, there is an interaction between teaching methods and learning interest Flip Classroom with STAD method is more effective than Traditional Instruction to teach reading to the students having high learning interest. The strategy emphasizes focusing learning individually before the 'real discussion' in Flip Classroom and 
mastering the material through students-centred in the form of small group learning. When the STAD method is applied in the reading class, the students are much more interested in the learning process. They feel that the learning method used is a media to explore their interest in English learning with the material learned in advance by Flip Classroom. They are more likely to speak openly in their teams. According to (Penny, 2000), the group-discussion method is first, increasing the depth of understanding; secondly, enhancing motivation and generating greater involvement; thirdly, developing positives attitudes toward later material presented in the lesson; fourthly, developing problem-solving skill, and practical problem.

Students with high learning interest have some characteristics: cooperative, selfconfident, responsible, leadership, and positive thinking. Students-centered learning should be owned by the students with high learning interest. They are challenged to do the best thing in group learning, not only for their personal goal but also their team achievement. Additionally, students believe that group learning improves their relationships with other students. Student can share what they have had and get something new from their group environment. The students with high learning interest are more active in teaching and learning process, they have bravery to consult their learning problem to their teacher. They are also brave to answer teacher's question whenever they are asked or not, they also have strong intention in learning activity, therefore, it makes them understand the lesson easily. (Elliot, 1999)state that interest occurs when a student's needs, capacities, and skills are good match for the demands offered by particular activity. The application of STAD method in the reading class can arouse the students' learning interest. Each student interacts with the teammates and they feel responsible to themselves or the other especially in helping their group member in facing material given. When the students' learning interest is high, it is expected that they can improve their competence and achievement optimally. Therefore, Flip Classroom with STAD method is effective to teach reading for students who have high learning interest.

The students who have low learning interest have some characteristics, such as: individualistic, unconfident, irresponsible, lack of leadership, and subjective thinking. They tend to regard that the easier way in mastering a set of English words and their roles are by translating them into their mother tongue. The students tend to focus on the meaning of each word and memorize them personally rather than its application in real life. The students' involvement in the learning process depends on their willingness to understand the subject of the lesson. Students who have low learning interest in a subject learn less effectively than 
students who are engaged (Fischer \& Horstendahl, 2004). Therefore, Traditional Instruction is more effective than Flip Classroom with STAD method to teach reading for the students who have low learning interest. Thus, it can be concluded that there is interaction between teaching methods and students' interest for teaching reading.

\section{CONCLUSION}

Based on the previous description of the data analysis, the writer can state the findings are as follows: (1) Flip Classroom with STAD method is more effective than Traditional Instruction to teach reading for the first semester students of Public Health; (2) Students having high learning interest have better reading achievement than students having low learning interest in the first year students of Public Health; and (3) There is interaction between teaching methods and learning interest in teaching reading for the first year students of Public Health. 


\section{BIBLIOGRAPHY}

Arbain, A. (2017). Techniques for Teaching Speaking Skill in Widya Gama Mahakam University. Script Journal: Journal of Linguistic and English Teaching, 2(1), 13-25. https://doi.org/https://doi.org/https://doi.org/10.24903/sj.v2i1.80

Elliot, S. N. et al. (1999). Educational Psychology: Effective Teaching, Effective Learning. New York: McGraw-Hill College.

Fischer \& Horstendahl. (2004). Motivation, Emotion, and Cognition. Retrieved from books.google.co.id/books

Fraenkel and Wallen. (2000). How to Design and Evaluate Research in Education. New York: Mc Graw - Hill, Inc.

Hurlock, E. B. (1983). Child Development. New Jerssey: Mc Graw-Hill.

McConel, D. (2006). E-Learning Groups and Communities. New York: Open University Press.

Network, F. L. (2014). The Four Pillars of FLIP ${ }^{\mathrm{TM}}$. Retrieved from http://www.ssfudes.com/veille/leveilleur/wpcontent/uploads/2014/09/FLIP_handout_FNL_Web.pdf

Nur, D. rahman. (2017). An analysis of the Feminist characters in Kate Chopin's "the awakening." Journal of English Educators Society, 2(1), 1-20. https://doi.org/http://dx.doi.org/10.21070/jees.v2i1.687

Penny, U. (2000). Discussions that work 'task-centred practice. New York: Cambridge university press.

Stone, B. B. (2012). Flip Your Classroom to Increase Active Learning and Student Engagement. Paper Presented at the Proceedings from 28th Annual Conference on Distance Teaching \& Learning, Madison.

Westwood, P. (2001). Reading and Learning Difficulties: Approaches to Teaching and Assessement. Hongkong: Acer Press. 